\title{
Development Of Islamic Education Course In Fostering Tolerant Characters In Students In Higher Education
}

\author{
W. Q. Suhendar ${ }^{1}$; R. Rahman ${ }^{2}$ \\ ${ }^{1}$ UL MKU Politeknik Negeri Bandung; ${ }^{2}$ FIS Universitas Negeri Padang \\ ${ }^{1}$ waway@polban.ac.id, ${ }^{2}$ rinirahman@fis.unp.ac.id
}

\begin{abstract}
This article is the author's idea regarding the application of contextual approaches in islamic education course at University. The purpose of writing this article is to find out how the strategy of developing students' tolerant characters through islamic education learning, as well as learning assesment methods can be used. The contextual approach encourages students to explore and elaborate every concept learned. In this approach, learning strategies take precedence and take precedence over results. Learners are directed to learn everything that is meaningful in their lives. Islamic education course with a contextual approach is carried out through assignments to students to plan, observe, and carry out the actualization of religious teachings in various social institutions that are in accordance with the themes set out earlier in the syllabus, and the RPS. Learning assesment can be carried out through assessment of understanding, sociometry, pretest and posttest, and responsiveness.
\end{abstract}

Keywords: Tolerant character, Islamic education, contextual approach

\section{Introduction}

This article is the author's idea of the strategy of developing students' tolerant characters through Islamic education. The regulation number 12 the year 2012 has explicitly mandated the content of students' character education to be academically involved in 4 courses. One of the courses is religious education. It has also been determined long ago by the government through Decree of the Minister of National Education Number 232/ U/2000 and number $045 / \mathrm{U} / 2002$, by including Religious Education in Higher Education as a Personality Development course[1].

Besides, another juridical basis that strengthens the existence of the PAI Course as a Guidance course for the tolerant character of students is the Minister of Religion Regulation number 5/2020 concerning the standard of implementing Islamic Education in Higher Education. Article 6 paragraph 2 states that the development of PAI material in tertiary institutions must consider the aspects of diversity, tolerance, and the development of science.

This tolerance becomes important to be studied and explored and instilled in students given the many verses and hadiths that assert that among the variables of a Muslim's faith is about acceptance of the reality of diversity and tolerance among others. Also, there are several teachings in the Prophet's hadith about the importance of tolerance developed in social life. Mention one of them in the hadith narrated by Imam Bukhari, where the Messenger of Allah was asked about the religion most loved by Allah. Then the Prophet answered that the religion that was loved by Allah was al Hanifiyyah al Samhah (a straight and tolerant religion).[2], [3] 
Furthermore, learning outcomes of Islamic education have been compiled in a lesson plan. It is mentioned that tolerant character is a part of the learning outcome of the course as seen in point S2 that are; contribute to improving the quality of the community, nation, state, and civilization progress based on Pancasila. Besides, KU1 in this course also points out the students can apply logical, critical, systematic, and innovative thinking in the context of the development or implementation of science and technology that sees and applies humanities following their fields of expertise.

Moreover, intolerant attitudes have recently begun to develop in educational institutions. Some survey results released by institutions such as the Center for the Study of Islamic Society (PPIM) UIN Syahid Jakarta and Setara Institute mention that the teachings of intolerance and radicalism have been understood in educational institutions in Indonesia. The results of a survey conducted by the Setara Institute on the tolerance of Indonesian students in 2016 stated that $35.7 \%$ of students had an intolerant understanding at the level of thought, as much as $2.4 \%$ had shown intolerant attitudes in actions and words, as much as $0.3 \%$ had the potential to become terrorists. This survey was conducted on 760 respondents who were studying in high schools in Jakarta and Bandung, West Java[4].

The findings from other studies are no less astonishing, it is said that intolerance and seeds of radicalism have entered and developed in schools. The results of 2017, research by PPIM UIN Jakarta conducted on students/teachers and teachers/lecturers from 34 provinces in Indonesia stated that as many as 34.3 percents of respondents had opinions of intolerance to other religious groups other than Islam. Also, as many as 48.95 percents of student respondents felt that religious education influenced them not to associate with followers of other religions. Even more surprising, 58.5 percent of student respondents/students have religious views with radical opinions[5].

These conditions, exacerbated by the rampant variety of information that can instill intolerant thinking in the minds of students in Indonesia. Recognized or not, among the reasons for the development of intolerant thinking is the opening of online-based information flow. The development of information technology that is so rapidly utilized by intolerant groups to increase the ideological network and propaganda they profess [6], [7].

This article tries to elaborate on the strategy of fostering tolerant characters through Islamic education learning at Universitas by using a contextual approach. This article is limited only in aspects of implementing the learning process and learning assesment. The contextual approach was chosen because the formulation of the learning outcomes in the lesson plan wants the students to have a comprehensive and integral understanding dealing with various problems in life, such as social, economic, political, or cultural.

\section{Method}

This article was compiled using a library research approach. Library research is a series of activities related to the collection of library data reviewing, records, and processing research material[8]. The main source in this article is the syllabus and lesson plans (RPS) at several higher education, while the supporting sources are Indonesia minister of religion regulation number 5/2020 concerning the standard of impelementating Islamic education in higher education, contextual learning theory, and the books that are relevant to the research topic. 


\section{Result And Discussion}

\subsection{Contextual Approaches in Islamic Education Course}

The contextual approach in learning is the result of the thought of John Dewey who departed from constructivism. This approach states that knowledge is developed by every human being in stages with the result that it can be developed in certain contexts [9]-[11]

The contextual approach is a learning concept that helps educators in linking the material with the students' experience. It also motivates them to be able to associate the knowledge they learn with their life experiences as family and community members. This concept by itself will lead them to be able to explore and elaborate learning material and relate it to reallife situations [12]-[14]

The contextual approach is a holistic and integral educational process that aims to encourage students to explore and elaborate on every concept learned[15]. The process of finding and solving a problem are methods that will direct students to find solutions to the problems they encounter without requiring special assistance from educators[16]. Then, the solution that the result excavation and assessment without specific direction will give the best results compared to the one that gets special assistance from educators. With this concept, the learning process can be carried out meaningfully for students. The learning carried out takes place naturally in the form of activities and experience[17]. It is not only about knowledge from educators to students.

Further, learning strategies take precedence over results in this approach. Then, learners are encouraged to learn the meaningful value in their lives, while educators role as directors and mentors and not merely as the source of learning[11], [13], [18], [19]. the development of contextual approaches in Islamic education begins through some stages. First, it links religious teachings with various fields of science that are explored and studied by students. Second, it connects students' understanding of Islamic norms and values with various problems in society. Third, it links Islamic teachings with their historical context. This approach is allegedly more flexible and dialogical between students and lecturers to discuss and solve various problems as topics in lectures [20].

\subsection{The Implementation of Contextual Approaches in Developing Tolerant Characters}

Islamic education course at universities as stipulated in Minister of Religious Regulation No. 5/2020 carried out by at least 2 credits. This credit provides students 100 minutes face-toface in class, 120 minutes class activities, and 120 independent activities referring to regulation No. 12/2012. The number of meetings in PAI various in the universities, ranging from 16 to 20 meetings. With such a large load, it is quite free for lecturers to apply contextual approaches in Islamic studies learning.

The main framework of the material developed in the PAI lectures in higher education can be divided into two parts. The themes discussed in the first section tend to discuss the methodology of Islamic studies. The themes discussed in this section revolve around the fundamentals of Islamic understanding, covering the themes of humanity, religion, sources of Islamic teachings, and points of Islamic teachings. Whereas in part two, the theme of the material developed discusses more themes relating to civilization, science, and life experiences of students in social environments. 


\subsection{Learning Process in Contextual Approach}

The main principle in the contextual approach is not to change the theme or number of meetings. Meanwhile, it purposes to shifts learning patterns that were previously dominated by lecturers or students play an important role in learning theoretically. In practice, students are given the motivation to be able to explore and elaborate material based on life experiences and relate it to the theme of the course. The role in the class can be seen from the picture as follows:

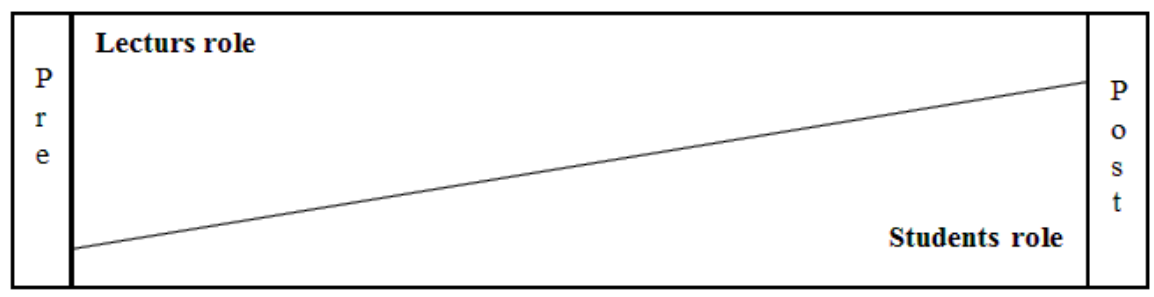

Fig.1. The role of lecturers and students in learning

The picture above shows the roles of lecturers and students. At the beginning of the meeting, lecturers are dominant to control the class than students. However, students play a dominant role than lecturers in the next development. This strategy aims to make students more proactive in exploring and elaborating on any phenomena that occur in their life and link them with religious understandings that previously explained by the lecturer.

The learning process in the Islamic education course is divided into two parts. They are before mid-examination and after the final examination. This learning process is conducted under conditions :

a. The first part is the material before the mid-test. In this section, the lecturers control the class. While the students are required to be able to put plans for the actualization of religious teachings based on the theme that will be delivered after the mid-test.

b. The actualization of religious teachings is done separately from face-to-face meetings in class. They are conducted as structured tasks or independent assignments.

c. The actualization of religious teachings is carried out within 7 meetings outside the classroom by students. The activities are planning, controlling, implementing, and reporting.

d. Students' report in every 50 minutes in the class is optimized for actualization under the guidance of the lecturer.

e. the lecturer directs the place that can be used as the object of students' actualization based on the themes, such as Islamic Economics, Marriage in Islam, Islamic Politics, Halal - Haram, Science and Technology, Culture, Islam in Indonesia (historical studies), and Morals.

f. The places to actualize are carried out in places that can bring out tolerant characters.

Table 1. The places such as shown in the chart below

\begin{tabular}{cll}
\hline Number & \multicolumn{1}{c}{ Themes } & \multicolumn{1}{c}{ Places } \\
\hline 1 & Economics & Market, Mall, Trading, Assurance, etc \\
2 & Family & $\begin{array}{l}\text { Religious Affairs Office, Religious Courts, District Courts, Civil } \\
\text { Registry Offices, Lower Communities }\end{array}$ \\
3 & Politic & $\begin{array}{l}\text { Political Parties, Youth Organizations, School Rohis, Islamic } \\
\text { Boarding Schools, etc. }\end{array}$
\end{tabular}




\begin{tabular}{cll}
4 & $\begin{array}{l}\text { Halal } \\
\text { Haram }\end{array}$ & $\begin{array}{l}\text { Halal Center, Halal Certification from Indonesia Ulema Council, } \\
\text { Islamic Organization, Market, etc }\end{array}$ \\
5 & $\begin{array}{l}\text { Science and } \\
\text { Technology }\end{array}$ & $\begin{array}{l}\text { Islamic Organizations, Culture and Art Council, Cultural Group, } \\
\text { Islamic Boarding Schools, Indigenous Peoples, Traditional } \\
\text { Ceremonies, etc. }\end{array}$ \\
6 & $\begin{array}{l}\text { Civilization } \\
\text { Mistorical Studies, Museums, Mosques, Churches, Temples, etc. } \\
\text { The Orphanage, Nursing Home, Shelter home, Beggar, etc }\end{array}$ \\
\hline
\end{tabular}

g. The second part is the meeting after the mid-test for 8 weeks. In this section, the students present their actualization results based on the case explored and reviewed. The role of the lecturers in class is to facilitate the students to relate the problems found during the actualization stage with the Islamic values, to find fundamental problems, and critically examine and offer solutions.

\subsection{Learning Assessment in Contextual Approach}

There are several aspects of assessment that can be used in the contextual approach :

a. Material Understanding

The material understanding assessment can be done through essays or multiplechoice test. This assessment is carried out at midterm and final term.

b. Sociometry

Sociometry is a grading system using peer assessment. They assess each other. The lecturers can ask several questions or instructions to the students to assess how the activities in the class or the group. The questions are related to who is the most diligent, who has the best religious understanding, who is the most diligent in the group, etc.

c. Pre-Test and Post-Test

Pre-test and Post-test are used to measure the students' development before and after learning activities. The assessment model is carried out by giving questionnaires to the students related to the students' tolerant character. This questionnaire is delivered at the first meeting, before mid-exam, and at the end of the meeting with the same type of questions.

d. Response

The response assessment is the assessment strategy and students' response to the Islamic education lecture. The lecturer gave several questions to the students related to the implementation of learning, material, assignments, delivery of material, and others related to the lectures. Then, the data from the student responses can not only be used to improve the learning process, but it can also be used as part of research on the effectiveness of the approaches used, as well as students' perceptions of Islamic education courses.

\section{Conclusion}

Based on the above study, the findings in this article are as follows:

a. The contextual approach can be applied in Islamic education courses at Universitas, in which the students are required to plan, observe, and carry out the actualization of the religious teaching in social institutions based on the themes discussed in lectures. 
b. The assessments in this approach include the material understanding assessment, sociometry, pre-test and post-test, and response.

\section{Acknowledgment}

The author would like to thank the Director the Head of the Research and Community Service Center of the Politeknik Negeri Bandung for the support of the authors. We would also like to thank the organizing committee for the opportunity to present this paper in the 4th ICSSED 2020

\section{References}

[1] W. Qodratulloh, "Persepsi Mahasiswa Terhadap Program Pendidikan Karakter Melalui Mentoring Pendidikan Agama Islam di Politeknik Negeri Bandung," Handayani, vol. 7, no. 1, pp. 13-19, 2017.

[2] Suryani, Hadis Tarbawi Analisis Paedagogis Hadis-hadis Nabi. Yogyakarta: Teras, 2012.

[3] A. Setiyawan, "Pendidikan toleransi dalam hadits nabi saw," J. Pendidik. Agama Islam, vol. XII, no. 2, pp. 219-228, 2015.

[4] A. Muthohar, "Radikalisme di Sekolah Swasta Islam Tiga Tipe Sekolah yang Rentang." [Online]. Available: https://theconversation.com/radikalisme-di-sekolah-swasta-islam-tiga-tipesekolah-yang-rentan-96722. [Accessed: 10-Jun-2020].

[5] S. Salim, "Strategi Mencegah Radikalisme di Sekolah." [Online]. Available: https://www.republika.co.id/berita/kolom/wacana/18/06/01/p9nc8j396-strategi-mencegahradikalisme-di-sekolah. [Accessed: 10-Jun-2020].

[6] A. S. Bakti, Deradikalisasi Dunia Maya Mencegah Simbiosis Terorisme dan Media. Jakarta: Daulat Press, 2016.

[7] I. F. Ghifari, "Radikalisme di internet," J. Agama dan Lintas Budaya, vol. 2, no. 1, pp. 123-134, 2017, doi: 10.15575/jw.v39i1.575.

[8] M. Zed, Metode Penelitian Kepustakaan. Jakarta: Yayasan Obor Indonesia, 2004.

[9] Rusman, Model-model Pembelajaran Mengembangkan Profesionalisme Guru. Jakarta: Rajawali Press, 2012.

[10] I. N. Yenti, "Pendekatan kontekstual (ctl) dan implikasinya dalam pembelajaran matematika," Ta'dib, vol. 12, no. 2, pp. 118-125, 2009 .

[11] A. Kadir, "Konsep pembelajaran kontekstual di sekolah,” Din. Ilmu, vol. 13, no. 3, pp. 17-38, 2013.

[12] E. Siregar and H. Nara, Teori Belajar dan Pembelajaran. Bogor: Galia Indonesia, 2014.

[13] A. Gafur, "Penerapan Konsep dan Prinsip Pembelajaran Kontekstual (Contextual Teaching and Learning) dan Desain Pesan dalam Pengembangan Pembelajaran dan Bahan Ajar," Cakrawala Pendidik., vol. XXII, no. 3, pp. 273-289, 2003.

[14] S. Kindarto and A. Gafur, "Pembelajaran Kontekstual dengan Strategi REACT Berbantuan Media untuk Meningkatkan Aktivitas dan Hasil Belajar IPS," J. Harmon. Sos. Vol. 1 Nomor 2, 2014, vol. 1, no. 2, pp. 213-230, 2014.

[15] Z. Aqib, Model-Model, Media, dan Strategi Pembelajaran Kontekstual (Inovatif). Bandung: Yrama Widya, 2013.

[16] S. Nasution, Berbagai Pendekatan dalam Proses Belajar Mengajar. Jakarta: Bumi Aksara, 2011.

[17] Nurhadi, Pembelajaran Kontekstual dan Penerapannya dalam KBK. Malang: Universitas 
Negeri Malang, 2004.

[18] E. B. Johnson, Contextual Teaching and Learning: Menjadikan Kegiatan Belajar Mengasikan dan Bermakna. Bandung: Mizan Media Utama, 2009.

[19] W. Q. S, "Konsep Ulul Albab dalam alQuran dan Implikasinya dalam Pembelajaran Pendidikan Agama Islam di Perguruan Tinggi," SigmaMU, vol. 8, no. 1, pp. 17-24, 2016.

[20] S. M. Towaf, "Pendekatan Kontekstual Bagi Pembelajaran Pendidikan Agama Islam di Perguruan Tinggi Umum," in Dinamika Pemikiran Islam di Perguruan Tinggi, Fuaduddin and C. H. Bisri, Eds. Jakarta: Logos Wacana Ilmu, 1999, p. 170. 